\title{
Ectogenesis and the case against the right to the death of the foetus
}

KEYWORDS: ectogenesis, foetus, abortion, moral status, infanticide, pregnancy

\section{ABSTRACT}

Ectogenesis, or the use of artificial wombs to allow a foetus to develop, will likely become a reality within a few decades, and could significantly affect the abortion debate. We first examine the implications for Judith Jarvis Thomson's violinist analogy, which argues for a woman's right to withdraw life support from the foetus and so terminate her pregnancy, even if the foetus is granted full moral status. We show that on Thomson's reasoning, there is no right to the death of the foetus, and abortion is not permissible if ectogenesis is available, provided it is safe and inexpensive. This raises the question of whether there are persuasive reasons for the right to the death of the foetus that could be exercised in the context of ectogenesis. Eric Mathison and Jeremy Davis have examined several arguments for this right, doubting that it exists, while Joona Räsänen has recently criticized their reasoning. We respond to Räsänen's analysis, concluding that his arguments are unsuccessful, and that there is no right to the death of the foetus in these circumstances.

\section{INTRODUCTION}

Ectogenesis describes the artificial means of supporting and growing an organism outside of its mother's body, during the period it would normally reside within her uterus. Although developing this technology is a complex endeavour, considerable progress has been made in 
the development of artificial environments for animal foetuses ${ }^{1}$, and it has been reported that one researcher has succeeded in cultivating human embryos in an artificial womb for up to ten days ${ }^{2}$. Given ectogenesis' application in the treatment of premature neonates, there is an incentive to continue development, and it also promises to bypass some of the ethical issues associated with surrogacy. Ectogenesis will also give women the opportunity to avoid the inherent risks of pregnancy and childbirth ${ }^{3}$. Progress is slow, but there is reason to believe that at some point in the future ectogenesis will become a reality.

Ectogenesis will have a far-reaching impact on the abortion debate. Mary Anne Warren writes that 'birth is morally significant because it marks the end of one relationship and the beginning of others. It marks the end of pregnancy, a relationship so intimate that it is impossible to extend the equal protection of the law to foetuses without severely infringing women's most basic rights ${ }^{3}$. Provided the technology encompasses the ability to safely extract an embryo or foetus from a pregnant woman, something we will assume in what follows, ectogenesis will enable this special relationship to be severed without killing the foetus. Any arguments for abortion that rely on the right to bodily autonomy or self defence will be impacted, shifting the debate to the question of whether there is a right to the death of the foetus. If there is not, then abortion is impermissible, given ectogenesis offers an alternative that allows the foetus to live.

\footnotetext{
${ }^{1}$ Partridge, E., et al (2017). An extra-uterine system to physiologically support the extreme premature lamb. Nature Communications, 8, 15112.

${ }^{2}$ Gelfand, S. and Shook, J. (2006). Ectogenesis. Kenilworth: Rodopi, p. 77.

${ }^{3}$ Smajdor, A. (2007). The Moral Imperative for Ectogenesis. Cambridge Quarterly of Healthcare Ethics, 16(03), 336-345.

${ }^{4}$ Warren, M.A. (1989). The Moral Significance of Birth. Hypatia, 4(3), 46-65.
} 
An important factor in this debate is the moral status of the extracted foetus. Something that possesses moral status is 'an entity towards which moral agents have, or can have, moral obligations ... we may not treat it in just any way we please' ${ }^{5}$. For example, if it is morally bad for an animal to suffer, it enjoys a degree of moral status. As Joona Räsänen ${ }^{6}$ has noted, if the foetus has no moral status at all, then no argument need be made. Ectogenesis and ending the life of the extracted foetus would be little different to cutting one's hair and discarding it. Conversely, if the extracted foetus is considered to have full moral status equivalent to that of an adult, then this implies the foetus has a right to life, and it is likely to be difficult to justify a right to its death. Many ethicists such as Jeff McMahan and Warren hold to a position between these extremes: while unwilling to grant full moral status to the foetus, they believe it nevertheless possesses partial moral status. This means that although the foetus has no right to life, 'we are morally obliged to give weight in our deliberations to its needs, interests or well-being'?

We begin by considering how the most widely debated argument for abortion is impacted by ectogenesis: Judith Jarvis Thomson's well known violinist analogy ${ }^{8}$. Currently, if her reasoning is accepted, it establishes abortion as permissible even if the foetus is granted full moral status, one of the few arguments to do so, and certainly the most important one. If Thomson's argument fails to establish a right to the death of the foetus, then we must look to other reasons.

\footnotetext{
${ }^{5}$ Warren, M.A. (1997). Moral Status: Obligations to Persons and Other Living Things. Clarendon Press, p. 3.

${ }^{6}$ Räsänen, J. (2017). Ectogenesis, abortion and a right to the death of the foetus. Bioethics 31(9), 697-702.

${ }^{7}$ Warren, op. cit. note 5, p. 3.

${ }^{8}$ Thomson, J.J. (1971). A defense of abortion. Philosophy and Public Affairs 1(1), 47-66.
} 
Recently, Christine Overall ${ }^{9}$ presented several arguments for the right to the death of the foetus. Eric Mathison and Jeremy Davis ${ }^{10}$ have subsequently examined and rejected three of the most plausible arguments for this right, and Räsänen ${ }^{11}$ has responded with a detailed reply.

A prerequisite for discussion is an understanding of what is meant by a right so that we can determine what is required to establish it. Mathison and Davis clarify that they are referring to an interest-based account of rights: 'a right is a significant interest that confers upon its possessor the power to make claims on others to respect or protect it ${ }^{\prime 2}$. To merely have an interest is not enough: the interest must be significant. According to Joseph Raz's prominent account, 'an interest is sufficient to base a right on if and only if there is a sound argument of which the conclusion is that a certain right exists ${ }^{13}$. Raz requires 'grounds for attributing to it the required importance ${ }^{14}$, together with reasons that demonstrate 'these grounds are not altogether outweighed by conflicting reasons ${ }^{15}$. Here, we reply to Räsänen, judging that his arguments do not provide sufficient grounds capable of overriding reasons not to kill the foetus, and concluding he is not successful in establishing a right to the death of the foetus.

\section{THOMSON'S VIOLINIST}

\footnotetext{
${ }^{9}$ Overall, C. (2015). Rethinking abortion, ectogenesis, and fetal death. Journal of Social Philosophy, 46, 126-140, 131.

${ }^{10}$ Mathison, E. \& Davis, J. (2017). Is there a right to the death of the foetus? Bioethics, 31, 313-320.

${ }^{11}$ Räsänen, op. cit. note 6.

${ }^{12}$ Mathison \& Davis, op. cit. note 10, p. 314.

${ }^{13}$ Raz, J. (1984). On the nature of rights. Mind 93 (370), 194-214, p. 209.

${ }^{14}$ Ibid: 209.

${ }^{15}$ Ibid: 209.
} 
Thomson's violinist argument for abortion ${ }^{16}$ is based on a thought experiment that constructs an analogy to pregnancy: a famous unconscious violinist who, while you were sleeping, has been attached to your body because you are the only person with the blood type who can help him recover from his kidney ailment. You are told that you cannot unplug yourself from him, because he has a right to life, and after all, it is only for nine months. After that period he will have recovered. Thomson appeals to our intuition that this would be an outrageous situation, and states that 'a right to life does not guarantee having either a right to be given the use of or a right to be allowed continued use of another person's body ${ }^{17}$. In Thomson's view, 'no-one is morally required to make large sacrifices, of health, of all other interests and concerns, of all other duties and commitments, for nine years, or even for nine months, in order to keep another person alive ${ }^{\prime 18}$. Thomson sees the woman who carries her foetus to full-term as a 'Good Samaritan' who voluntarily goes beyond what is morally required of her.

We do not intend to enter the ongoing debate as to whether Thomson succeeds in justifying abortion. Our interest here is how ectogenesis will impact her argument. It is crucial to note that Thomson does not advocate the death of the foetus, but rather its removal. For Thomson, abortion is a means to terminate pregnancy, not the life of the foetus, although currently, terminating pregnancy will inevitably result in its death. She writes that 'the desire for the child's death is not one which anybody may gratify, should it turn out to be possible to detach the child alive ${ }^{19}$. Thomson does not believe there is a right to the death of the foetus; indeed, she is clear that in the case of the violinist 'you have no right to be guaranteed his death, by

\footnotetext{
${ }^{16}$ Thomson, op. cit. note 8, pp. 48-49.

${ }^{17}$ Ibid: 56.

${ }^{18}$ Ibid: 64 .

${ }^{19}$ Ibid: 66.
} 
some other means, if unplugging yourself does not kill him ${ }^{20}$. As I. Glenn Cohen notes with regard to Thomson, 'the right enjoyed by women is a right to stop gestating, not a right to end the existence of the fetus' ${ }^{21}$, while David Boonin summarises her argument as 'the right to life does not include or entail the right to life support ${ }^{22}$. In the case of pregnancy, this life support is provided by the foetus's mother, and so she is entitled to withdraw that support by the only means possible: aborting the foetus.

Ectogenesis severs the link between termination of pregnancy and the death of the foetus. Provided ectogenesis is safe, which we have assumed, and affordable, the mother can withdraw the life support she is providing without harming the foetus, and without a 'Good Samaritan' sacrifice being required of her. Instead, the foetus's life support can be supplied by an artificial womb that we are assuming is not a burden on its parents, financially or otherwise. How safe and affordable compared to abortion must ectogenesis be to avoid being a 'Good Samaritan' sacrifice? We agree with McMahan that it can be allowed that ectogenesis can be significantly worse than abortion, but not substantially worse: 'she is morally required to accept some costs in order to remove it alive rather than to kill it' ${ }^{23}$. Provided these costs are not substantially worse, and recalling that Thomson grants the foetus full moral status, abortion is not permissible and ectogenesis must be utilised if the pregnancy is to be ended. As McMahan states, 'it is simply not plausible to suppose that she may permissibly kill her own child rather than remove it alive, even at somewhat greater cost to herself ${ }^{24}$.

\footnotetext{
${ }^{20}$ Thomson, op. cit. note 8, p. 66 .

${ }^{21}$ Cohen, I. Glenn (2017). Artificial Wombs and Abortion Rights. Hastings Center Report 47(4), inside back cover.

${ }^{22}$ Boonin, D. (2002). A Defense of Abortion. New York, NY: Cambridge University Press, p. 137.

${ }^{23}$ McMahan, Jeff (2007). Infanticide. Utilitas 19 (2),:131-159, p. 26.

${ }^{24}$ McMahan, op. cit. note 23, p. 26.
} 


\section{THE RIGHT TO THE DEATH OF THE FOETUS}

We have shown that according to Thomson's reasoning, there is no right to the death of the foetus, and so if ectogenesis is available, we are morally obliged to utilise it for unwanted pregnancies rather than aborting the foetus. If we grant the foetus full moral status, it is then difficult to envisage any situation where a right to its death could be justified. This is because the foetus' accompanying right to life can only be overridden in very specific circumstances: what is called justifiable homicide. Kate Greasley states that 'the clearest example of justified homicide recognized in law and in morality is that of killing in self defence ${ }^{25}$. Two crucial requirements for justified self defence are necessity and proportionality: it must avert more harm than it causes. Clearly, ectogenesis entails there can be no necessity for killing the foetus in self defence against bodily intrusion. Although killing the foetus may still be the only way to prevent other harms such as the psychological trauma of unwanted parenthood, killing to avoid these harms in the event that the foetus has full moral status is clearly disproportionate. We conclude that if the foetus is granted full moral status, there can be no right to its death.

If the foetus is granted only partial moral status, we cannot assume it possesses a right to life, and there may be sufficient reasons to justify a right to its death in order to benefit humans who already possess full moral status, such as avoiding certain harms. This could be accomplished by either choosing abortion or killing the foetus once it has been extracted. These reasons must be substantial to justify killing a viable human being possessing some

\footnotetext{
${ }^{25}$ Greasley, K. (2017). Arguments About Abortion: Personhood, Morality, and Law. Oxford: Oxford University Press, p. 59.
} 
moral status. The absence of a right to life does not imply the foetus can be killed with impunity or gratuitously. As Singer and Wells note in response to the claim that the woman still has a right in this situation to decide if her foetus lives or dies, 'it is difficult to see why a healthy foetus should die if there is someone who wishes to adopt it and give it the opportunity of a worthwhile life, ${ }^{26}$.

We will now consider some of these reasons that have been advanced, purporting to justify a right to the death of the foetus. Mathison and Davis ${ }^{27}$ have examined three of what they regard to be the most plausible arguments for the right of the death of the foetus, which were initially advanced by Overall ${ }^{28}$. Their first argument is the biological parents rights' argument, and they consider whether certain harms experienced by giving up a child for adoption justify the right to the foetus' death. Mathison and Davis also note that we intuitively believe that other biological relatives such as grandparents or siblings do not have a right to the death of the foetus, and ask why the parental biological relationship grounds such a right only for a specified time, during pregnancy.

Mathison and Davis then consider the right to one's genetic privacy. They argue that even if we grant such a right, at most this applies to one's entire genome. A child contains only $50 \%$ of each parent's genetic material, and it is difficult to see how this is a morally important threshold, given close relatives also contain substantial portions of our genetic material. The final argument they examine is the right to property, based 'along Lockean lines that we own

\footnotetext{
${ }^{26}$ Singer, P. and Wells, D. (1984). The reproduction revolution: New ways of making babies. Oxford: Oxford University Press, p. 135.

${ }^{27}$ Mathison \& Davis, op. cit. note 10, pp. 313-320.

${ }^{28}$ Overall, op. cit. note 8, p. 131.
} 
our bodies, and also the fruits of our labour' ${ }^{29}$ - in fact the mixed labour of both parents. Mathison and Davis point out that the labour of others is involved in IVF, such as doctors, but they acquire no property rights. They also note that 'there is no clear place where the property claim can be justified ${ }^{30}$ working back from adult to a foetus. Mathison and Davis conclude that these arguments do not succeed in justifying a right to the death of the foetus, and they doubt such a right exists.

Räsänen ${ }^{31}$ has responded to Mathison and Davis, examining each argument and presenting his own case as to why they constitute valid reasons that together ground a right to the death of the foetus. We now examine each of Räsänen's arguments in turn.

\section{THE RIGHT NOT TO BECOME A BIOLOGICAL PARENT}

Räsänen's first argument states there is 'the right not to become a biological parent' ${ }^{32}$, echoing Overall's claim that for women, abortion is 'acting upon their legitimate reproductive right not to become a biological parent ${ }^{\prime 33}$. Here Räsänen is clear that the term 'biological parent' refers to a genetic parent. Given that the adults concerned are already biological parents, we suggest calling this the right not to be a biological parent. Abortion does not stop one becoming a biological parent, rather, it provides a means for the biological parents to cease being one.

\footnotetext{
${ }^{29}$ Mathison \& Davis, op. cit. note 10, p. 318.

${ }^{30}$ Ibid: 319.

${ }^{31}$ Räsänen, op. cit. note 6, pp. 697-702.

${ }^{32}$ Ibid: 698.

${ }^{33}$ Overall, op. cit. note 9, p. 131.
} 
Räsänen's reasoning is that 'becoming a biological parent causes harm to the couple because of parental obligations towards the child' and in fact that 'the harms in question are parental obligations ${ }^{34}$. In his view, parental obligations can never be completely eliminated, even by adoption. Consequently, parents have a right to avoid these harms, and the only way of doing so is by ensuring the death of the foetus.

Firstly, we object to Räsänen's notion that parental obligations are harms. Many parents happily fulfill their parental obligations and would deny that this has harmed them.

Obligations themselves are not harms, although we grant that possessing certain obligations may result in harm. It is the nature of some obligations that they may be difficult to satisfy, and that doing so may be detrimental to those under obligation, causing them harm. More importantly, that certain obligations result in harm does not necessarily justify avoiding those obligations. For example, if we make a promise, and we realise that keeping that promise will result in harm to us, this does not mean our obligation to keep the promise should be avoided, although it could be argued that severe, unexpected harms may mitigate our obligation, depending on the circumstances. Of course, it could be argued that abortion is analogous to avoiding making a promise to take on parental obligations. Räsänen, however, claims that 'when a man and woman are having sex, they implicitly accept the possible consequences of their activity ${ }^{35}$, and he approvingly quotes Rivka Weinberg who states 'we assume the costs (and rewards) of that risky activity ${ }^{36}$. According to Weinberg, however, these costs include incurring parental obligations. The question then becomes, under what circumstances may these incurred parental obligations be repudiated by killing the foetus? Given that we grant

\footnotetext{
${ }^{34}$ Räsänen, op. cit. note 6, p. 698.

${ }^{35}$ Ibid: 699.

${ }^{36}$ Weinberg, R. (2015). The risk of a lifetime: How, when, and why procreation may be permissible. Oxford, UK: Oxford University Press, p. 67.
} 
the foetus has some moral status, it would seem that ectogenesis followed by adoption should be obligatory, unless the resulting harms are significant.

What harms may parents suffer as a result of relinquishing the foetus to adoption? Both Räsänen, and Mathison and Davis cite Cohen's concept of 'attributional parenthood' ${ }^{37}$, a social attitude where genetic parents are treated as though they have the same moral obligations as custodial parents, leading to discrimination and negative attitudes from others. They also note that a 'lingering sense of obligation toward the child' could cause psychological harm. There are other possibilities not explored by Räsänen: depending on adoption laws, the child may seek contact with its parents some time in the future, and this could cause distress ${ }^{38}$.

Are these potential harms sufficient to justify the death of the foetus instead of utilising adoption? What Räsänen seems not to have considered is that the death of the foetus also carries the risk of both psychological and societal harm. Some studies have shown that abortion may increase the risk of some mental health issues ${ }^{39}$, and if someone may experience a lingering sense of obligation towards a child who has been adopted into another family and never seen again, it seems possible they could also feel a similar sense of obligation towards a child who might have existed had they not chosen to end its life. Also, in a society where

\footnotetext{
${ }^{37}$ Cohen, I. Glenn (2008). The Right Not to Be a Genetic Parent? Southern California Law Review, 81(6), 1115-1196.

${ }^{38}$ March, K. (2014). Birth Mother Grief and the Challenge of Adoption Reunion Contact. The American Journal of Orthopsychiatry. 84. 409-419.

${ }^{39}$ Fergusson, D. Horwood, L. and Boden, J. (2013). Does abortion reduce the mental health risks of unwanted or unintended pregnancy? A re-appraisal of the evidence. Australian \& New Zealand Journal of Psychiatry, 47(9), 819-827; Coleman, P.K. (2011). Abortion and mental health: quantitative synthesis and analysis of research published 1995-2009. The British Journal of Psychiatry 199(3), 180-186.
} 
ectogenesis is widespread, it seems plausible that there may well be negative social attitudes towards those who choose to kill the foetus, especially given the elimination of concerns about bodily autonomy. So whether ectogenesis is followed by adoption or the foetus is killed, harm could result, and it seems difficult to determine in advance which option would be most harmful. It could be argued that a decision to kill the foetus must be made on a case by case basis, but this is not a right to not be a biological parent.

\section{THE RIGHT TO GENETIC PRIVACY}

Räsänen claims that 'if ectogenesis abortions become reality, some women (and men) will have genetic children out there who carry their genetic material without their consent. In this scenario, their right to genetic privacy has been violated, and the only way to avoid this is if they have a right to the death of the foetus ${ }^{30}$. To build his case, Räsänen provides a thought experiment of a mad scientist who steals someone's DNA and gestates a foetus identical to them in an artificial womb. Räsänen believes this demonstrates that their right to genetic privacy has been violated, and consequently they have a right to the death of the foetus.

Mathison and Davis note that scenarios such as this do not establish a right to genetic privacy, but rather point to a right that our genetic information should not be misused. There are reasons why we might deny a right to genetic privacy, or to at least allow it to be overridden. For example, it might be that a spouse has a right to know if their partner has a genetic condition that could influence a decision to have children, or that children have a

\footnotetext{
${ }^{40}$ Räsänen, op. cit. note 6, p. 699.
} 
right to know if they are likely to have inherited a disease. Räsänen has not provided sufficient grounds for a right to genetic privacy, undermining his argument at the outset.

Let us grant, though, that a right to genetic privacy may exist and explore what this means here. Mathison and Davis claim that the mother's right to genetic privacy is not violated because the foetus only has $50 \%$ of her genetic code, raising the question of how much of our genetic code must be disclosed for a violation. Is it credible to claim that having children violates our right to genetic privacy, implying we must consent to this violation? It cannot be that the existence of other close relatives who also share a portion of our genetic code violates our genetic privacy, so as Mathison and Davis ask, what is the moral difference when it comes to the foetus? This widespread availability of portions of our genetic code seems incompatible with a broad right to genetic privacy. It suggests that having children does not violate any right we have to genetic privacy, and seems to favour our earlier point that the right in question is more likely to be misuse of genetic information rather than privacy.

Räsänen appears to grant Mathison and Davis's point about the foetus possessing only $50 \%$ of each parents' genetic code, stating that 'this line of reasoning explains only why the genetic mother has no right to the death of the fetus ${ }^{41}$. He attempts to counter it by arguing that the right to genetic privacy is a collective right. Räsänen states that 'even though a foetus shares $50 \%$ of its genetic material with each genetic parent respectively, $100 \%$ of the foetus' genetic material comes from its genetic parents' and so 'the genetic parents together have a right to the death of the fetus ${ }^{\prime 42}$. However that $100 \%$ of the foetus' genetic material comes from its parents seems irrelevant with respect to genetic privacy: what matters is how much

\footnotetext{
${ }^{41}$ Räsänen, op. cit. note 6, p. 700.

${ }^{42}$ Ibid: 700.
} 
of the parents' individual genetic codes are disclosed. If the disclosure is not sufficient for either the mother or father to possess the right to the death of the foetus, then it is not sufficient at all. As Peter Jones explains, a requirement of a collective right is that members of the group "jointly possess a right that none of them possesses individually" ${ }^{43}$. Rights already held by individuals within the group, such as privacy rights, do not constitute collective rights. The right to genetic privacy also fails Jones' requirement that 'a right is a group right only if it is borne by the group qua group' ${ }^{44}$. There is no collective parental genetic code - there is only the genetic code of each individual parent.

It seems that what Räsänen actually means here is that there is a collective right to the death of the foetus that is grounded on the violation of each parent's genetic privacy. But this raises a crucial point: if we do grant a right to genetic privacy exists, and even allow that the foetus violates this right, how does this entail the parents have the right to the death of the foetus? If someone violates our rights in some way, say by stealing from us, we do not normally address the violation by killing them. We certainly do not have the right to kill them: violation of a right does not entail the right to kill the violator. Likewise, in the case here concerning a viable foetus possessing some moral status, there can be no automatic right to its death.

As an aside, it is worth mentioning that references to $50 \%$ of each parent's genetic code being shared with the foetus can be misleading. Although the foetus does inherit $50 \%$ of its genetic code from each parent, this does not entail $50 \%$ of each parent's genetic code can be

\footnotetext{
${ }^{43}$ Jones, P. (1999). Human Rights, Group Rights, and People's Rights. Human Rights Quarterly, 21(1), 80-107.

${ }^{44}$ Ibid: 82.
} 
recovered from the foetus's genetic code. The foetus's genetic code is a mix of its parents' genetic codes, and for most alleles, or gene variants, there is no way of determining which parent contributed the allele $\mathrm{e}^{45}$, and very little of each parents' genetic code can be obtained. This strengthens our claim that it seems unlikely that the existence of the foetus constitutes a violation of a right to genetic privacy, should that right exist.

\section{THE RIGHT TO PROPERTY}

Räsänen's final argument is that the foetus is the collective property of its parents, and so their consent is required for it to be placed in ectogenesis, or alternatively, they can choose to destroy it. We agree with Räsänen when he states that 'obviously, children are not parents' property ${ }^{46}$. But we question his reasoning that 'children are not property because children are persons: morally valuable individuals ${ }^{47}$. We also agree that persons cannot be property, but Räsänen has previously defended a threshold view for persons, and argued that infants 'are

\footnotetext{
${ }^{45}$ There are some exceptions: in autosomal recessive inheritance, if the foetus has both copies of a faulty gene, then it is known that each parent must carry at least one copy of the faulty gene, although they may just be carriers and unaffected. In X-linked inheritance, if a male foetus has a faulty gene, it must have originated in the mother, as fathers cannot pass on X-linked traits. Similarly, in Y-linked inheritance, faulty genes can only pass from father to son. Finally, mitochondrial inheritance applies to the 37 genes found in mitochondrial DNA, which is only passed on by females. Mitochondrial DNA has a very high mutation rate, estimated as at least an order of magnitude greater than nuclear DNA, and so a mutation in a child's mitochondrial DNA may not be reflected in their mother. See: Griffiths, A., et al (2000). An Introduction to Genetic Analysis. 7th edition. New York: W. H. Freeman, 41-52, and Tuppen, H., Blakely, E., Turnbull, D. and Taylor, R. (2010). Mitochondrial DNA mutations and human disease. Biochimica et Biophysica Acta (BBA) - Bioenergetics, 1797(2), 113-128. So of perhaps 20,000 genes in the human genome, 37 genes of a mother may be determined from their child's mitochondrial DNA, and in the event that the child has an inherited disorder, there is a possibility that it can be deduced that a parent possesses the same faulty gene (in the case of Xand Y-linked disorders). Otherwise, a parent's genetic code cannot be determined from their child's, unless the other parent's genetic code is known or their child has an obvious genetic disorder .

${ }^{46}$ Räsänen, op. cit. note 6, p. 701.

${ }^{47}$ Ibid: 701.
} 
not even close to that threshold ${ }^{48}$. With his view that persons cannot be property, does Räsänen mean to imply the converse, that human non-persons are property? Or are there some non-persons such as infants that are also not property?

If it is the former, this would entail under his threshold view of persons that some infants are property as well as foetuses, and further suggests that if there is a right to the death of a foetus, there is likewise a right to the death of the infant - even if it is healthy. As an aside, we can further speculate that if infants are property (and not persons), then other morally contentious acts may be also be permissible ${ }^{49}$.

Conversely, if Räsänen believes children of any age, including infants, are not the property of their parents, then being a person cannot be the criterion he is using to determine property status. In that case, when does the transition from property to non-property status occur? As Mathison and Davis point out 'there is no clear place where the property claim can be justified ${ }^{50}$. The only realistic candidate seems to be birth itself, i.e. when the foetus begins an existence independent from its mother - the point at which it is no longer referred to as a foetus. This becomes problematic in the case of ectogenesis, as it enables the foetus to begin an independent existence far earlier, possibly even from conception if combined with in-vitro fertilisation (IVF). The point of viability has a similar issue, as it is generally understood to be the ability of the foetus to survive outside its mother's womb, irrespective of supporting technology that may be required.

\footnotetext{
${ }^{48}$ Räsänen, J. (2016). Pro-Life Arguments Against Infanticide and Why they are Not Convincing. Bioethics 30 (9), 656-662, p. 660.

${ }^{49}$ Rodger, D., Blackshaw, B. and Miller, C. (2018). Beyond Infanticide: How Psychological Accounts of Persons Can Justify Harming Infants. The New Bioethics, 24(2), 106-121.

${ }^{50}$ Mathison \& Davis, op. cit. note 10, p. 319.
} 
We note too that IVF blastocysts start from a position of non-independence from their mother, and, if transferred, become dependent until birth. This demonstrates what is known as an episodic problem: if used as a criterion, the foetus's status as property or non-property comes and goes depending on its location. A far less problematic conceptual stance is to conclude, as do Mathison and Davis, that embryos and foetuses are not the property of their parents.

Finally, we note that even if it is granted that the ectogenesis foetus is the property of its parents, this does not necessarily entail a right to its death. Räsänen states that it is 'commonly believed that people have a right to destroy their property' ${ }^{51}$, and criticises Mathison and Davis' example of a historic building that has intrinsic value and cannot be destroyed. Historic buildings and pieces of art do not have moral status, and if, as Räsänen grants here, the foetus has some moral status, they do not seem comparable. A better comparison might be pets, which Mathison and Davis raise but do not elaborate on. We grant our pets some degree of moral status, as they are sentient beings, agreeing, for example, they should not be subject to suffering without substantial justification. We do not destroy pets if they are unwanted and there are people eager to give them a home. Similarly, even if the foetus is the property of its parents, this does not entail or justify a right to its death.

\section{CONCLUSION}

\footnotetext{
${ }^{51}$ Räsänen, op. cit. note 6, p. 701.
} 
We have established that when ectogenesis is available and developed to a degree where it is safe and inexpensive, Thomson's violinist analogy, which grants that the foetus may possess full moral status, does not justify a right to the death of the foetus. The only other argument for abortion that grants full moral status is justifiable homicide, and this is untenable if ectogenesis is available. We conclude that in the event the foetus is granted full moral status, there is no right to the death of the foetus, and abortion is impermissible.

If the foetus is granted partial moral status, it consequently lacks a right to life, and a right to its death is easier to justify. However we have examined Räsänen's arguments for the right to the death of the foetus, and have found they are unpersuasive in providing significant reasons for grounding such a right. We do not believe there is a right to not be a biological parent, even if it could be shown that it is permissible to kill the foetus in certain circumstances. Räsänen has not established a right to genetic privacy, and even if this right is granted, the existence of the foetus is unlikely to violate this right. If we were to concede that it does, a right to its death does not follow. If embryos and foetuses are not the property of their parents, as we surmise, they do not have the right to destroy them. We have also noted that owning property does not necessarily entail a right to destruction of property. We conclude that proponents of the right to the death of the foetus will need to find stronger arguments to justify overriding the presumption that a viable human being with at least some moral status should not be killed.

\section{ACKNOWLEDGEMENTS}


We would like to thank two anonymous referees and Jeremy Williams for their extremely helpful comments on earlier versions of this paper. 